\title{
Isolation of endophytic fungi from benalu batu (Begonia Medicinalis) and their toxicity on Artemia Salina
}

\section{Isolasi jamur endofit dari benalu batu (Begonia Medicinalis) dan toksisitasnya terhadap Artemia Salina}

\author{
Syariful Anam ${ }^{1 *}$, Armini Syamsidi ${ }^{1}$, Musyahidah $^{1}$, Nurul Ambianti ${ }^{1}$, Agustinus Widodo ${ }^{1}$, \\ Muhammad Sulaiman Zubair ${ }^{1}$
}

${ }^{1}$ Jurusan Farmasi, Fakultas MIPA, Universitas Tadulako, Palu, Indonesia

*Corresponding author: syarifulanam1@gmail.com

\begin{abstract}
Background: Endophytic fungi are microorganisms found in plant tissues that are mutually beneficial to the host plant. They are known as sources of bioactive metabolites which possess various biological activities such as antimicrobial, anticancer, antiviral, antifungal, and antioxidant. Benalu batu (Begonia medicinalis) has been used empirically as a medicinal plant and has shown anticancer activity in breast cancer cells (T47D cells) and cervical cancer cells (HeLa cells).

Objective: This study aimed to isolate the endophytic fungi from benalu batu and determine the toxicity activity and Lethal Concentration $50 \%\left(\mathrm{LC}_{50}\right)$ value of isolated endophytic fungi using shrimp larvae (Artemia salina).

Method: Endophytic fungi were isolated from fresh parts; leaves, stems, roots of Benalu Batu. The selected parts were sterilized with ethanol $70 \%$ and sodium hypochlorite $1 \%$ subsequently placed into Potato Dextrose Agar Chloramphenicol (PDAC) then incubated at $28^{\circ} \mathrm{C}$ for 7 days. Isolated endophytic fungi were extracted by sonication method using ethyl acetate. The toxicity activity of isolated endophytic fungi was determined using the Brine Shrimp Lethality Test (BSLT).

Results: Isolation of the endophytic fungi from benalu batu obtained 10 isolates, which the leaves part obtained 6 isolates, the stem obtained 3 isolates and the root obtained 1 isolate. The results of screening for toxicity test of 10 isolates at concentrations of $500 \mu \mathrm{g} / \mathrm{mL}$ shown that isolate D3, D5, and D6 gave $100 \%$ mortality. The $\mathrm{LC}_{50}$ values of isolate D3, D5, and D6 were obtained respectively in $448.03,8.784$, and $9.13 \mu \mathrm{g} / \mathrm{mL}$.

Conclusion: These results indicated that isolate D5 exhibits the greatest toxicity and needs to be investigated the activity for testing on cancer cells.
\end{abstract}

Keywords: endophytic fungi, Begonia medicinalis, toxicity, Artemia salina

\section{Intisari}

Latar belakang: Jamur endofit merupakan mikroorganisme yang terdapat dalam jaringan tumbuhan yang bersifat mutualisme terhadap tumbuhan inang. Jamur endofit telah diketahui sebagai sumber metabolit yang memiliki beberapa aktivitas biologi seperti antimikroba, antikanker, antivirus, antijamur, dan antioksidan. Tumbuhan benalu batu (B. medicinalis) telah digunakan secara empiris dan terbukti memiliki aktivitas antikanker pada sel kanker payudara (Sel T47D) dan sel kanker leher rahim (Sel HeLa). Tujuan: Studi ini bertujuan untuk melakukan isolasi jamur endofit dari benalu batu dan mengetahui toksisitas isolat jamur endofit serta menentukan nilai Lethal Concentration $50 \%$ (LC $\mathrm{L}_{50}$ ) terhadap larva udang (Artemia salina)

Metode: Jamur endofit diisolasi dari bagian segar; daun, batang, akar benalu batu. Bagian-bagian tersebut disterilisasi dengan etanol $70 \%$ dan natrium hipoklorit $1 \%$ selanjutnya diletakkan pada media Potato Dextrose Agar Chloramphenicol (PDAC) kemudian diinkubasi pada suhu $28^{\circ} \mathrm{C}$ selama 7 hari. Isolat jamur endofit diekstraksi dengan metode sonikasi menggunakan etil asetat. Aktivitas toksisitas isolat jamur endofit ditentukan menggunakan metode Brine Shrimp Lethality Test (BSLT).

Hasil: Isolasi jamur endofit dari benalu batu diperoleh 10 isolat, bagian daun diperoleh 6 isolat, bagian batang diperoleh 3 isolat dan bagian akar diperoleh 1 isolat. Hasil penapisan uji toksisitas 10 isolat pada konsentrasi $500 \mu \mathrm{g} / \mathrm{mL}$ menunjukkan bahwa isolat D3, D5, dan D6 memberikan persentase mortalitas 
sebesar 100\%. Nilai LC50 isolat D3, D5, dan D6 diperoleh masing-masing sebesar 448,03, 8,784, dan 9,13 $\mu \mathrm{g} / \mathrm{mL}$.

Kesimpulan: Hasil ini menunjukkan isolat D5 memiliki toksisitas paling besar dan perlu dilanjutkan untuk pengujian pada sel kanker.

Kata kunci : jamur endofit, Begonia medicinalis, toksisitas, Artemia salina

\section{Pendahuluan}

Produk alami merupakan metabolit sekunder yang berasal dari tumbuhan, hewan, dan mikroorganisme seperti alkaloid, terpen, steroid, poliketida, lignan, ester, flavonoid (Newman \& Cragg, 2016). Ratusan produk alami tersebut telah memasuki tahap pengembangan hingga ke fase klinik, diantaranya sebagai antikanker dan antimikroba (Newman \& Cragg, 2020). Paclitaxel yang diisolasi dari Taxus brevifolia (Roopa et al., 2015) dan camptothecin (Li et al., 2017) yang diisolasi dari Camptotheca acuminate merupakan contoh metabolit yang diperoleh dari tumbuhan dengan aktivitas sebagai antikanker. Namun demikian, isolasi metabolit dari tumbuhan memiliki beberapa tantangan diantaranya membutuhkan lahan dan mengancam keberlangsungan tumbuhan tersebut yang sebagian besar adalah spesies langka serta kandungan metabolit yang dapat berubah disebabkan faktor tempat tumbuh dan iklim yang berubah (Kharwar et al., 2011). Oleh karena itu, penggunaan mikroorganisme yang memiliki sifat simbiosis mutualisme dengan tumbuhan seperti jamur endofit merupakan salah satu cara alternatif dalam memproduksi suatu metabolit baru yang berpotensi sebagai bahan baku obat baru.

Jamur endofit merupakan mikroorganisme yang terdapat dalam jaringan tumbuhan yang bersifat mutualisme terhadap tumbuhan inang dimana mikroorganisme ini tidak menyebabkan kerusakan pada tumbuhan inangnya (Jia et al., 2016; Malik et al., 2020). Jamur endofit telah diketahui berperan sebagai sumber metabolit yang memiliki beberapa aktivitas biologi seperti antimikroba, antikanker, antivirus, antijamur, dan antioksidan (Jalgaonwala et al., 2017). Pemanfaatan jamur endofit sebagai sumber metabolit berkembang pesat disebabkan diantaranya kemampuannya dalam memproduksi metabolit tanpa harus menggunakan lahan dan waktu yang relatif singkat dan berdampak baik pada konservasi tumbuhan khususnya spesies langka (de Carvalho et al., 2021).

Studi ini menggunakan salah satu tumbuhan endemik Sulawesi Tengah khususnya masyarakat suku Wana Kabupaten Morowali Utara dalam penyembuhan penyakit tumor yaitu tumbuhan benalu batu (Begonia sp) (Anam et al., 2014). Penelitian sebelumnya, ditemukan golongan senyawa metabolit sekunder yang terdapat pada benalu batu yaitu flavonoid, polifenol, tanin dan saponin (Ritna et al., 2016). Tumbuhan ini juga memiliki aktivitas sitotoksik terhadap sel kanker payudara (T47D) dan sel kanker leher rahim (HeLa), dimana senyawa yang bertanggung jawab terhadap aktivitas tersebut yaitu glikosida steroid (Zubair et al., 2020; 
Zubair et al., 2021). Pada penelitian lainnya, fraksi dari benalu batu (B. medicinalis) terbukti memiliki aktivitas antioksidan dan antivirus (Zubair et al., 2021). Oleh karena itu, studi ini dilakukan dengan tujuan untuk melakukan isolasi jamur endofit dari benalu batu dan mengetahui toksisitas isolat jamur endofit serta menentukan nilai Lethal Concentration 50\% (LC50) terhadap larva udang (Artemia salina), studi ini diharapkan menghasilkan isolat jamur endofit yang memiliki aktivitas biologi sehingga dapat menjadi sumber metabolit dan bahan baku obat dimasa depan.

\section{Metode}

\subsection{Alat dan bahan}

Dalam penelitian ini digunakan beberapa peralatan antara lain: autoklaf (Eleya®), oven (Oxone), laminar air flow (LAF) (Stremline $®)$ ), inkubator (EyeleSLI®400), mikroskop binokuler (Olympus), Sonikator (DELTA D68H Ultrasonic Cleaner), Erlenmeyer (Pirex®), gelas kimia (Pirex®), cawan petri (Pirex®), gelas ukur (Pirex®), mikropipet (Socorex), timbangan analitik (Ohaus $\AA$ ).

Bahan yang digunakan dalam penelitian ini adalah benalu batu (B. medicinalis) meliputi daun, batang dan akar dari tumbuhan tersebut, medium Potato Dextrose Agar (PDA) (Merck), kloramfenikol, air suling steril (Water One), Etanol 70\% (Brataco), Natrium hipoklorit 1\%, Dimethyl Sulfoxide (DMSO) (Merck), metanol, etil asetat (Brataco), lempeng KLT G60 F254 (Merck), dan larva udang (Artemia salina).

\subsection{Pengambilan dan identifikasi sampel tumbuhan}

Pengambilan sampel tumbuhan benalu batu dilakukan di Desa Wawopada, Kecamatan Lembo, Kabupaten Morowali Utara, Propinsi Sulawesi Tengah. Tumbuhan diidentifikasi di Unit Pelaksana Teknis (UPT) Sumber Daya Hayati Sulawesi Tengah (Herbarium Celebense) Universitas Tadulako Palu.

\subsection{Isolasi jamur endofit}

Prosedur isolasi jamur endofit menggunakan metode tanam langsung mengikuti (Hasiani, 2015; Malik et al., 2020) dengan sedikit modifikasi yaitu sampel berupa daun, batang dan akar dicuci dengan air suling steril, direndam etanol 70\% selama 2 menit, larutan natrium hipoklorit 1\% selama 2 menit dan terakhir dibilas dengan air suling steril sebanyak tiga kali. Selanjutnya, potongan sampel dikeringkan di atas kasa steril. Sampel bagian daun, batang dan akar dipotong kecil kemudian diletakkan di media PDAC (Potato Dextrosa Agar Chloramphenicol) dengan posisi permukaan belahan yang telah dikerik menempel pada agar medium. Tiap cawan berisi 3 potongan sampel. Prosedur isolasi dilakukan di dalam Laminar Air Flow (LAF), dan selanjutnya sampel diinkubasi selama $7 \times 24$ jam pada suhu $28^{\circ} \mathrm{C}$. Isolat endofit yang menunjukkan sifat morfologi jamur dipindahkan ke media PDAC yang baru. 


\subsection{Pemurnian jamur endofit}

Jamur endofit yang telah tumbuh pada media isolasi PDAC, kemudian secara bertahap dimurnikan. Masing-masing isolat murni jamur endofit yang diperoleh, kemudian dipindahkan ke dalam media PDAC baru. Pemurnian ini bertujuan untuk memisahkan koloni endofit dengan morfologi berbeda untuk dijadikan isolat tersendiri. Pengamatan makroskopik dilakukan setelah 5-7 hari, apabila masih ditemukan koloni yang berbeda maka harus dipisahkan kembali sampai diperoleh isolat murni. Isolat murni kemudian disimpan sebagai stok kultur (Hasiani, 2015).

\subsection{Karakterisasi jamur endofit}

Karakterisasi isolat jamur endofit dilakukan dengan cara makroskopik dengan mengamati warna dari koloni isolat jamur endofit dan secara mikroskopik langsung (Hasiani, 2015). Pengamatan mikroskopik dilakukan dengan menggunakan mikroskop yaitu cuplikan isolat diletakkan pada kaca objek lalu ditetesi methylene blue setelah itu dilakukan pengamatan yang meliputi pengamatan hifa, spora, konidia (Suhartina et al., 2018).

\subsection{Ekstraksi jamur endofit}

Isolat jamur endofit diinokulasi tiga titik pada media PDA sebanyak lima petri, selanjutnya diinkubasi pada suhu $28^{\circ} \mathrm{C}$ selama 7 hari. Setelah 7 hari, isolat endofit diekstraksi sebanyak dua kali menggunakan alat sonikator pada frekuensi $48 \mathrm{KHz}$ selama 30 menit dengan merendam isolat jamur endofit dalam $100 \mathrm{~mL}$ pelarut etil asetat. selanjutnya disaring dan filtrat diuapkan hingga diperoleh ekstrak kental (Malik et al., 2020)

\subsection{Pengujian toksisitas secara Brine Shrimp Lethalitiy Test (BSLT)}

Pengujian ini dimodifikasi dari penelitian sebelumnya (Puspitasari et al., 2018) yang menggunakan vial $10 \mathrm{~mL}$ diisi dengan $500 \mu \mathrm{L}$ larutan uji (pada penapisan awal diperoleh dari 10 isolat jamur endofit yang dilakukan dengan menggunakan konsentrasi akhir dalam vial 500 $\mu \mathrm{g} / \mathrm{mL}$. Pada penentuan nilai $\mathrm{LC}_{50}$ isolat jamur endofit D3, D5, dan D6 dibuat seri konsentrasi akhir dalam vial 500, 250, 125, 62,5, 31,25, 15,62, 7,8 dan 3,9 $\mu \mathrm{g} / \mathrm{mL}$. Adapun untuk kontrol DMSO digunakan konsentrasi akhir dalam vial 2\%). Selanjutnya, ditambahkan air laut buatan dan 10 ekor larva A. salina yang telah berumur 48 jam, kemudian ditambah dengan air laut buatan hingga mencapai volume $5 \mathrm{~mL}$. Setiap konsentrasi dilakukan tiga kali pengulangan dan dibandingkan dengan kontrol DMSO. Pengujian ini dilakukan selama 24 jam kemudian dilihat jumlah kematian larva A. salina.

Uji toksisitas dari suatu sampel ditentukan dengan besar nilai dari $\mathrm{LC}_{50}$ yang dapat mematikan $50 \%$ populasi A. salina. Efek toksisitas dianalisis dari pengamatan dengan menghitung persen kematian sesuai dengan rumus berikut :

$$
\text { Persen Kematian }=\frac{(\text { jumlah larva kontrol }- \text { jumlah larva hidup }) \times 100 \%}{\text { jumlah larva kontrol }}
$$


Selanjutnya dibuat plot antara konsentrasi dan persen kematian larva dengan menggunakan program GraFit versi 5.0 (Erithacus Software Limited, Horley, Surrey, RH6 9YJ, UK): untuk memperoleh nilai $\mathrm{LC}_{50}$.

\section{Hasil dan pembahasan}

\subsection{Identifikasi sampel tumbuhan}

Sampel tumbuhan benalu batu (B. medicinalis) yang digunakan pada penelitian ini yaitu bagian daun, batang dan akar. Tumbuhan ini diperoleh dari Desa Wawopada, Kabupaten Morowali Utara Provinsi Sulawesi Tengah. Proses identifikasi sampel tumbuhan dilakukan di Unit Pelaksana Teknis (UPT) Sumber Daya Hayati Sulawesi Tengah (Herbarium Celebense) Universitas Tadulako Palu yang menyatakan bahwa sampel tumbuhan ini adalah benar tumbuhan benalu batu (Begonia medicinalis).

\subsection{Isolasi jamur endofit}

Jumlah isolat jamur endofit yang telah berhasil diisolasi dari bagian daun, batang dan akar benalu batu dapat dilihat pada gambar di bawah ini :

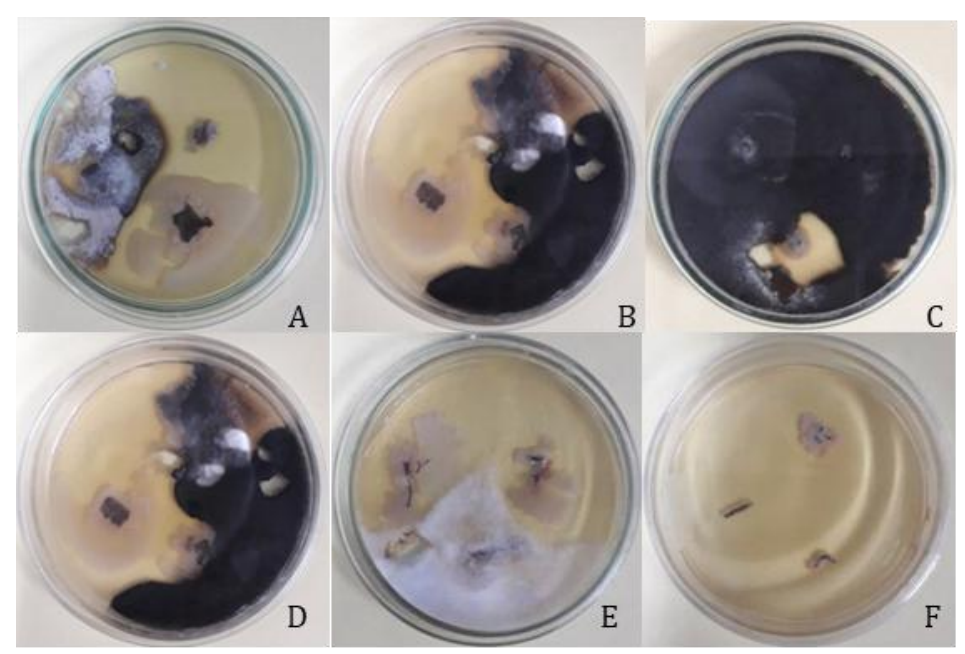

Gambar 1. Hasil isolasi jamur endofi dari berbagai bagian dari tumbuhan benalu batu (B. medicinalis) $\mathrm{A}=$ bagian daun petri $1, \mathrm{~B}=$ bagian daun petri $2, \mathrm{C}=$ bagian batang petri $1, \mathrm{D}=$ bagian batang petri $2, \mathrm{E}=$ bagian akar petri $1, \mathrm{~F}=$ bagian akar petri 2

Pengamatan makromorfologi pada cawan petri hasil isolasi jamur endofit pada Gambar 1 tampak koloni yang tumbuh adalah koloni jamur, dengan demikian proses isolasi yang dilakukan pada bagian daun, batang dan akar berhasil dan dilanjutkan pada proses pemurnian isolat jamur endofit. Pada gambar 1A dan 1B yang merupakan bagian daun menunjukkan diversifikasi koloni yang beragam dengan ditandai bentuk dan warna koloni yang beragam. Hal ini berbanding terbalik dengan bagaian akar (gambar $1 \mathrm{E}$ dan $1 \mathrm{~F}$ ) terlihat hanya 1 koloni yang tumbuh. 


\subsection{Pemurnian jamur endofit}

Proses pemurnian dilakukan dengan mencuplik isolat jamur pada petri isolasi (Gambar 1) berdasarkan perbedaan bentuk dan warna koloni. Cuplikan tersebut ditumbuhkan kembali pada media PDAC yang baru dan diamati setelah inkubasi 5-7 hari, dan hasil pemurnian menunjukkan hanya satu koloni yang tumbuh. Hasil pemurnian diperoleh 10 isolat yang memberikan penampakan makromorfologi yang berbeda satu dengan lainnya, yaitu 6 isolat dari bagian daun (kode D1 sampai D6), 3 isolat dari bagian batang (kode B1 sampai B3) dan 1 isolat dari bagian akar (kode A1). Adapun hasil pemurnian isolat jamur endofit dapat dilihat pada gambar di bawah ini :

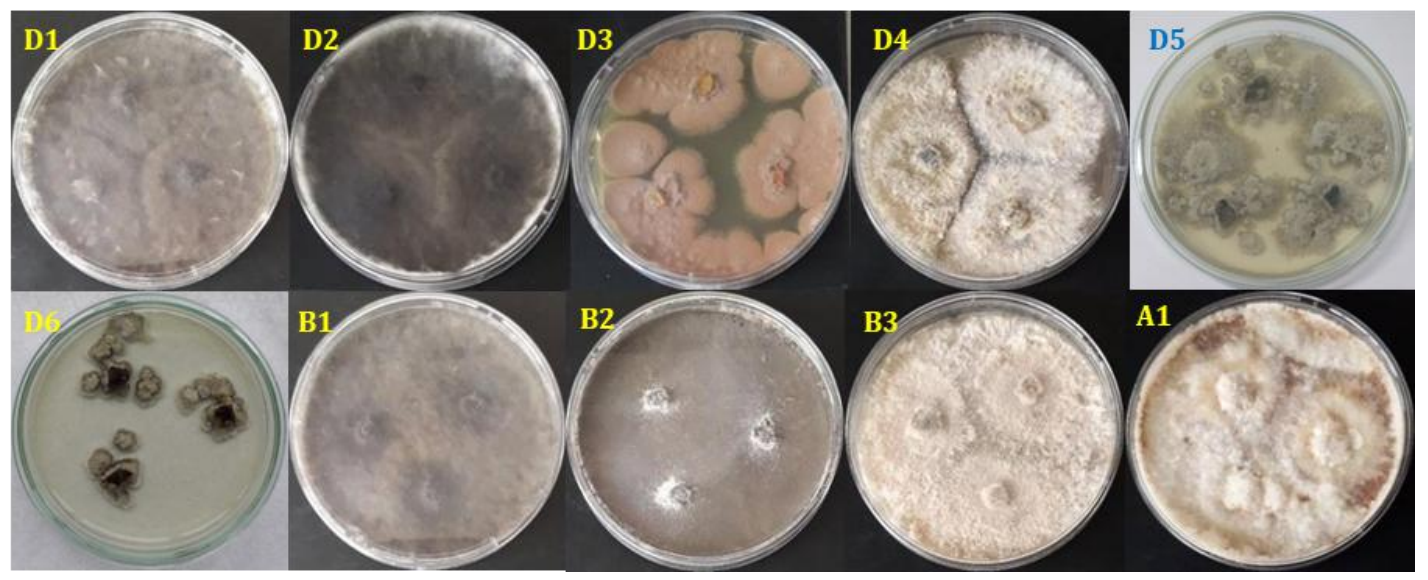

Gambar 2. Isolat murni jamur endofit dari daun, batang dan akar benalu batu (B. medicinalis) D1=isolat daun 1, D2=isolat daun 2, D3=isolat daun 3, D4=isolat daun 4, D5=isolat daun 5, D6=isolat daun 6, B1=isolat batang 1, B2=isolat batang 2, B3=isolat batang 3, A1=isolat akar 1

\subsection{Karakterisasi jamur endofit}

Karakterisasi isolat jamur endofit dapat dilakukan dengan tiga cara yaitu makroskopik (pengamatan bentuk dan warna koloni menggunakan mata), mikroskopik (pengamatan bentuk spora, hifa, konidia menggunakan alat mikroskop), dan molekuler (identifikasi dengan mengekstraksi DNA). Studi ini hanya dibatasi dengan melakukan karakterisasi secara makroskopik dan mikroskopik. Karakterisasi isolat murni jamur endofit dapat dilihat pada Tabel 1 dan Gambar 3.

Tabel 1. Makroskopik isolat jamur endofit Benalu batu (B. medicinalis)

\begin{tabular}{ccl} 
No. & Kode isolat & \multicolumn{1}{c}{ Karakteristik makroskopik isolat jamur endofit } \\
\hline 1. & D1 & $\begin{array}{l}\text { Koloni mula-mula berwarna hitam putih, tumbuh kurang lebih sekitar 3 } \\
\text { hari, setelah } 7 \text { hari berwarna hitam, pertumbuhan koloni rata, tebal, } \\
\text { berserabut dan sangat lunak. }\end{array}$ \\
\hline 2. & D2 & $\begin{array}{l}\text { Koloni berwarna hitam putih, setelah } 7 \text { hari berwarna hitam, } \\
\text { pertumbuhan koloni berserabut tebal, lunak dan rata. }\end{array}$ \\
\hline 3. & D3 & $\begin{array}{l}\text { Koloni berwarna coklat, tidak berserabut, tumbuh sekitar } 3 \text { hari, } \\
\text { pertumbuhan koloni tipis, sangat lunak dan tidak merata. }\end{array}$ \\
\hline 4. & D4 & $\begin{array}{l}\text { Koloni berwarna putih, berserabut, pertumbuhan koloni tipis, sangat } \\
\text { lunak dan merata, tumbuh sekitar 3 hari. }\end{array}$ \\
\hline 5. & D5 & $\begin{array}{l}\text { Koloni berwarna putih, ditengah terdapat warna hitam, koloni tidak } \\
\text { berserabut serta agak keras, pertumbuhan koloni tipis dan tidak merata. }\end{array}$ \\
\hline
\end{tabular}




\begin{tabular}{ccl}
\hline No. & Kode isolat & \multicolumn{1}{c}{ Karakteristik makroskopik isolat jamur endofit } \\
\hline 6. & D6 & $\begin{array}{l}\text { Koloni berwarna putih, ditengah terdapat warna hitam, koloni tidak } \\
\text { berserabut dan agak keras, pertumbuhan koloni tipis dan tidak merata. }\end{array}$ \\
\hline 7. & B1 & $\begin{array}{l}\text { Koloni berwarna hitam puth, tumbuh sekitar } 3 \text { hari, setelah } 7 \text { hari } \\
\text { berwarna hitam, memiliki serabut, sangat lunak, pertumbuhan koloni } \\
\text { tebal dan rata. }\end{array}$ \\
\hline 8. & B2 & $\begin{array}{l}\text { Koloni berwarna hitam, tumbuh sekitar 3 hari, setelah } 7 \text { hari tetap } \\
\text { berwarna hitam, tidak memiliki serabut, pertumbuhan koloni tipis, lunak } \\
\text { dan merata. }\end{array}$ \\
\hline 9. & B3 & $\begin{array}{l}\text { Koloni berwarna putih, tumbuh sekitar 3 hari, setelah 7 hari tetap } \\
\text { berwarna putih, memiliki serabut tipis, pertumbuhan koloni merata dan } \\
\text { sangat lunak. }\end{array}$ \\
\hline 10. & A1 & $\begin{array}{l}\text { Koloni berwarna putih, tumbuh sekitar 3 hari, pertumbuhan koloni } \\
\text { merata dan tebal setelah 7 hari, memiliki serabut serta lunak. }\end{array}$ \\
\hline
\end{tabular}
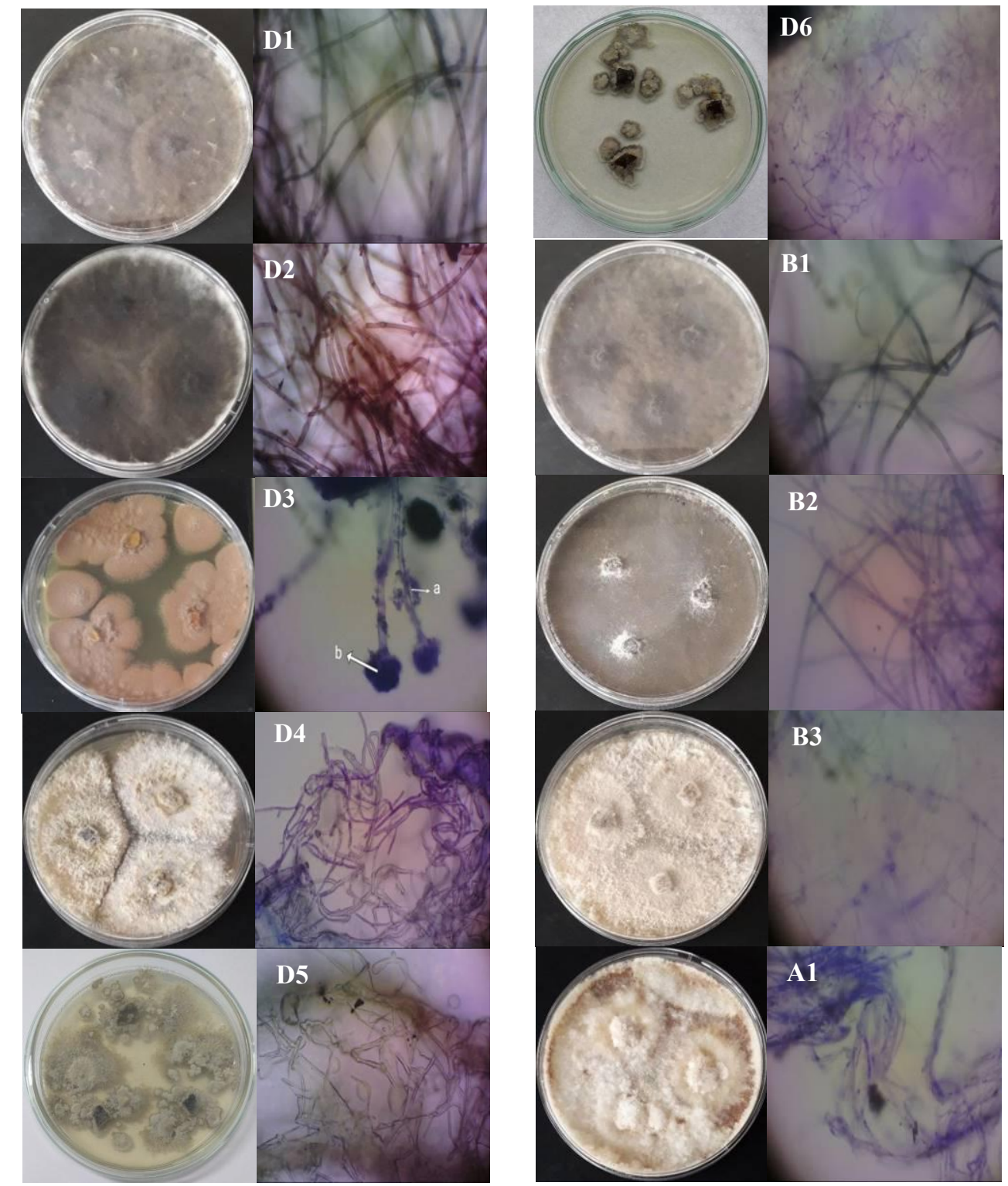

Gambar 3. Pengamatan makroskopik dan mikroskopik isolat murni jamur endofit tumbuhan benalu batu (B. medicinalis) dengan perbesaran 400x

D1=isolat daun 1, D2=isolat daun 2, D3=isolat daun 3, D4=isolat daun 4, D5=isolat daun 5, D6=isolat daun 6, B1=isolat batang 1, B2=isolat batang 2, B3=isolat batang 3, A1=isolat akar 
Karakterisasi mikroskopik isolat jamur endofit dilakukan dengan menggunakan mikroskop pada perbesaran 400 kali. Pada gambar terlihat sebagian besar pengamatan terhadap isolat jamur endofit hanya mampu memperlihatkan hifa, namun spora dan konidia tidak dapat terlihat dengan baik. Oleh karena itu, studi ini sangat merekomendasikan karakterisasi dan identifikasi secara molekuler, khususnya isolat jamur endofit yang memberikan aktivitas pada larva A. salina.

\subsection{Pengujian toksisitas secara Brine Shrimp Lethalitiy Test (BSLT)}

Isolat jamur endofit murni selanjutnya diekstraksi sebanyak dua kali secara sonikasi menggunakan pelarut etil asetat. Kemudian hasil ekstraksi disaring menggunakan kertas saring lalu diuapkan hingga diperoleh ekstrak kental. Ekstrak yang telah diperoleh diuji kemampuan toksisitasnya terhadap larva A. Salina dengan metode Brine Shrimp Lethality Test (BSLT). Larva A. salina digunakan sebagai bioindikator pada studi ini karena metode ini mudah, sederhana, membutuhkan sampel relatif sedikit dan larva ini memiliki kepekaan yang cukup tinggi (Puspitasari et al., 2018). Oleh karena itu, uji toksisitas menggunakan larva ini digunakan sebagai penapisan awal yang dapat memberikan korelasi positif dengan daya sitotoksik bahan uji terhadap sel kanker, sehingga diharapkan studi ini akan memberikan rekomendasi isolat dan ekstrak isolat jamur endofit yang memiliki aktivitas terhadap A. salina untuk dilanjutkan pada pengujian menggunakan sel kanker .

Penapisan awal uji toksisitas dari 10 ekstrak isolat jamur dilakukan menggunakan metode BSLT pada konsentrasi $500 \mu \mathrm{g} / \mathrm{ml}$, dengan tujuan mengetahui ekstrak yang dapat memberikan persen kematian larva udang yang tinggi. Hasil penapisan awal ini diperoleh tiga ekstrak isolat jamur endofit yang memiliki persen kematian sebesar 100\% yaitu ekstrak isolat D3, D5, dan D6, dimana kontrol DMSO tidak menyebabkan kematian pada larva. Adapun hasil penapisan awal ini dapat dilihat pada gambar di bawah ini :

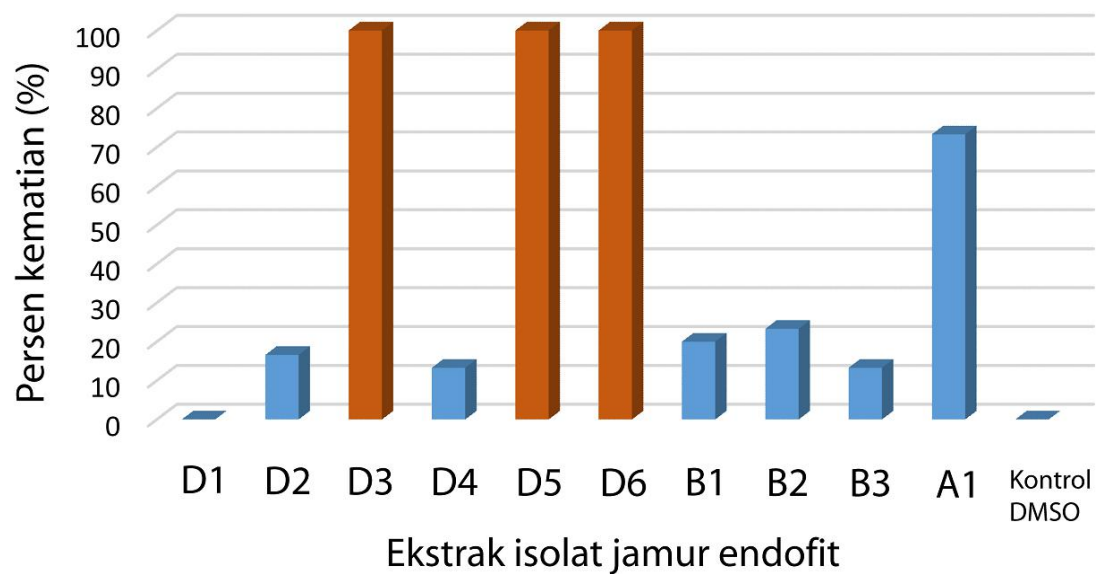

Gambar 4. Penapisan awal toksisitas 10 isolat jamur endofit B. medicinalis pada konsentrasi 500 $\mu \mathrm{g} / \mathrm{mL}$ 
Ekstrak isolat D3, D5, dan D6, selanjutnya ditentukan nilai LC 50 menggunakan prosedur BSLT dengan membuat seri konsentrasi 500, 250, 125, 62,5, 31,25, 15,62, 7,8, dan 3,9 $\mu \mathrm{g} / \mathrm{ml}$. Nilai $\mathrm{LC}_{50}$ diperoleh dari analisis data esktrak isolat jamur endofit D3, D5, dan D6 menggunakan program GraFit versi 5.0. Adapun nilai $\mathrm{LC}_{50}$ dapat dilihat pada tabel di bawah ini :

Tabel 2. Nilai $\mathrm{LC}_{50}$ ekstrak isolat jamur endofit D3, D5, dan D6

\begin{tabular}{cc}
\hline Ekstrak isolat jamur endofit & Nilai $\mathbf{L C}_{\mathbf{5 0}}(\boldsymbol{\mu g} \mathbf{/ m L})^{*}$ \\
\hline D3 & $448,03 \pm 482,8$ \\
\hline D5 & $8,784 \pm 0,018$ \\
\hline D6 & $9,13 \pm 7,36$ \\
\hline \multicolumn{2}{c}{${ }^{*}$ rata-rata dari 3 kali ulangan pengujian }
\end{tabular}

Hasil dari uji BSLT pada ekstrak isolat jamur endofit, diperoleh nilai $\mathrm{LC}_{50}$ untuk ekstrak isolat D3, D5, dan D6 yaitu 448,03; 8,784; dan $9.13 \mu \mathrm{g} / \mathrm{ml}$. Menurut (Carballo et al., 2002) apabila nilai $\mathrm{LC}_{50}<1000 \mu \mathrm{g} / \mathrm{ml}$ maka suatu ekstrak dikatakan toksik berdasarkan metode BSLT. Semakin besar nilai $\mathrm{LC}_{50}$ maka semakin kecil toksisitasnya, sebaliknya makin kecil nilai $\mathrm{LC}_{50}$ maka toksisitasnya lebih besar. Hasil pengujian menunjukkan bahwa ekstrak isolat D3 memiliki efek toksisitas lebih rendah dan ekstrak isolat D5 dan D6 memiliki efek toksisitas yang lebih besar terhadap larva A. salina. Grafik hubungan antara konsentrasi dengan persen kematian ekstrak isolat jamur endofit diplot dengan menggunakan program GraFit versi 5.0, pada grafik terlihat bahwa grafik ekstrak isolat D5 membentuk kurva sigmoid sedangkan dua isolat lainnya tidak membentuk kurva sigmoid. Hal ini menunjukkan data nilai $\mathrm{LC}_{50}$ pada isolat $\mathrm{D} 5$ valid dan hal ini sejalan dengan nilai deviasi dari $\mathrm{LC}_{50}$ yang kecil. Grafik antara hubungan konsentrasi dengan persen kematian ekstrak isolat D3, D5, dan D6 dapat dilihat pada gambar di bawah ini :

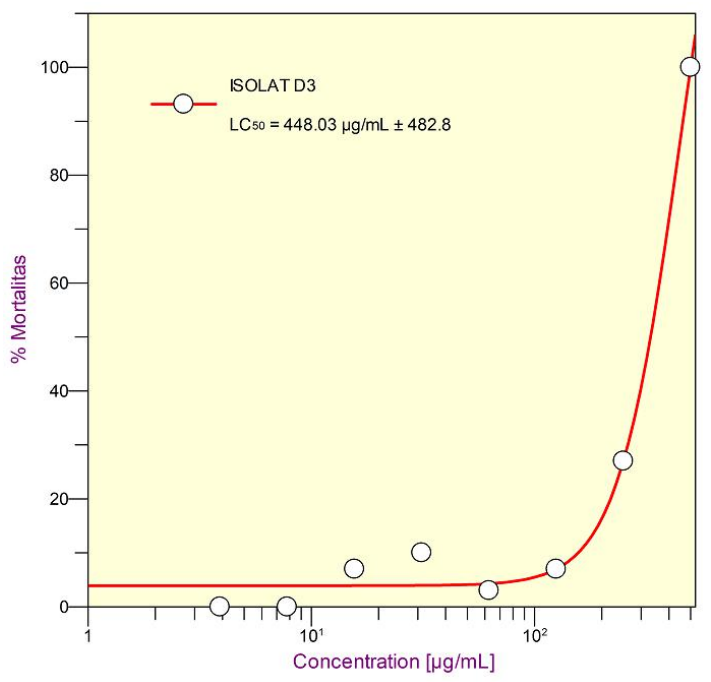

A

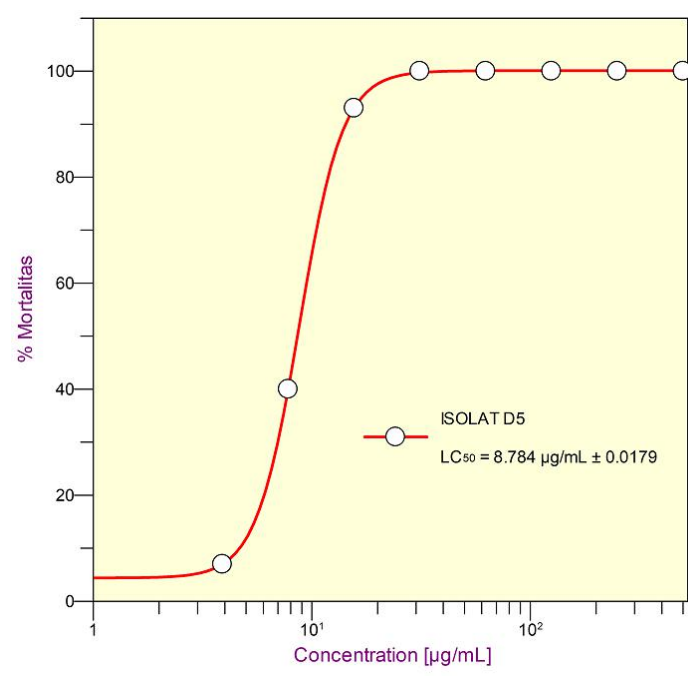

$\mathrm{B}$ 


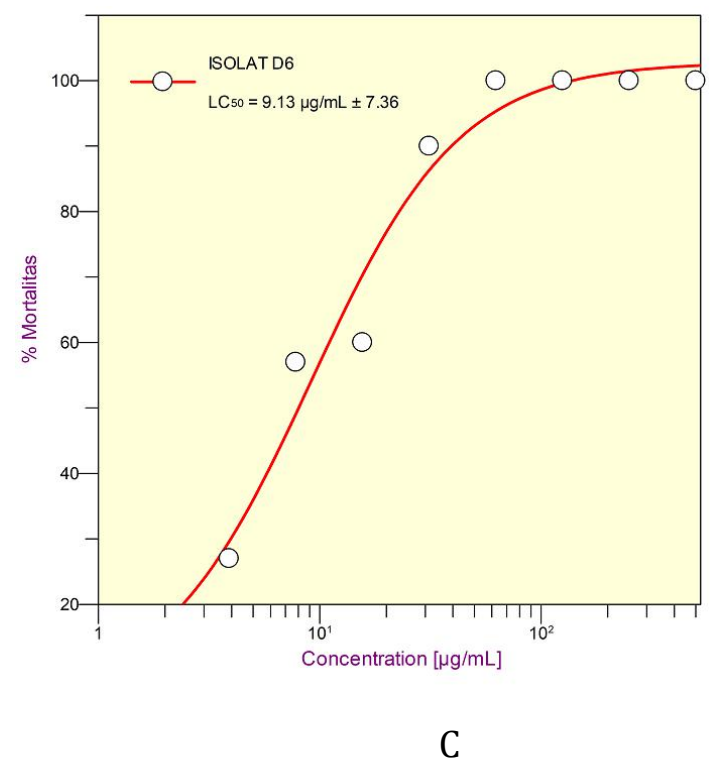

Gambar 5. Grafik hubungan antara konsentrasi ekstrak isolat jamur endofit dengan persen kematian larva udang.

$\mathrm{A}=$ ekstrak isolat jamur endofit D3; B=ekstrak isolat jamur endofit D5; C=ekstrak isolat jamur endofit D6

\section{Kesimpulan}

Studi isolasi jamur endofit yang berasal dari benalu batu (B. medicinalis) diperoleh 10 isolat jamur endofit yang terdiri dari bagian daun diperoleh (enam isolat), bagian batang (tiga isolat), dan bagian akar (satu isolat). Penapisan awal uji toksisitas 10 isolat terhadap A. salina diperoleh isolat D3, D5, dan D6 memberikan persen kematian 100\% dimana isolat jamur endofit D5 memiliki potensi yang besar dengan nilai $\mathrm{LC}_{50}$ sebesar $8,784 \pm 0,018 \mu \mathrm{g} / \mathrm{ml}$ sehingga direkomendasikan untuk pengujian lanjut pada sel kanker.

\section{Ucapan terimakasih}

Ucapan terimakasih kepada Universitas Tadulako melalui Program Hibah Dana Penelitian Unggulan Universitas Tadulako DIPA Fakultas MIPA tahun 2021.

\section{Daftar pustaka}

Anam, S., Yuliet, Y., Ritna, A., Dwimurti, F., Rismayanti, D., \& Zubair, M. S. (2014). Aktivitas Sitotoksik Ekstrak Metanol Benalu Batu (Begonia sp.): Ethnomedicine Suku Wana Sulawesi Tengah. Jurnal Ilmu Kefarmasian Indonesia, 12 (1), 10-16.

Carballo, J. L., Hernández-Inda, Z. L., Pérez, P., \& García-Grávalos, M. D. (2002). A Comparison between Two Brine Shrimp Assays to Detect In Vitro Cytotoxicity in Marine Natural Products. BMC Biotechnol, 2, 17. doi:10.1186/1472-6750-2-17

de Carvalho, C. R., Maia, M. Q., Sobral, M., Pereira, G. M. D., da Silva, K., Vital, M. J. S., Zilli, J. É., Rosa, C. A., \& Rosa, L. H. (2021). Diversity and antimicrobial activity of culturable endophytic fungi associated with the neotropical ethnomedicinal plants Copaifera langsdorffii and Copaifera pubiflora. South African Journal of Botany, 142, 305-315. doi:https://doi.org/10.1016/j.sajb.2021.06.021 
Hasiani, V. V., Ahmad, I., \& Rijai, L. (2015). Isolasi Jamur Endofit dan Produksi Metabolit Sekunder Antioksidan dari Daun Pacar (Lawsonia inermis L.). Jurnal Sains dan kesehatan, 1(4), 146-153. doi:https://doi.org/10.25026/jsk.v1i4.32

Jalgaonwala, R. E., Mohite, B. V., \& Mahajan, R. T. (2017). A Review: Natural Products from Plant Associated Endophytic Fungi. Journal of Microbiology and Biotechnology Research, 1, 2132.

Jia, M., Chen, L., Xin, H. L., Zheng, C. J., Rahman, K., Han, T., \& Qin, L. P. (2016). A Friendly Relationship between Endophytic Fungi and Medicinal Plants: A Systematic Review. Front Microbiol, 7, 906. doi:10.3389/fmicb.2016.00906

Kharwar, R. N., Mishra, A., Gond, S. K., Stierle, A., \& Stierle, D. (2011). Anticancer Compounds Derived from Fungal Endophytes: Their Importance and Future Challenges. Nat Prod Rep, 28(7), 1208-1228. doi:10.1039/c1np00008j

Li, F., Jiang, T., Li, Q., \& Ling, X. (2017). Camptothecin (CPT) and Its Derivatives are Known to Target Topoisomerase I (Top1) as Their Mechanism of Action: Did We Miss something in CPT Analogue Molecular Targets for Treating Human Disease such As Cancer? Am J Cancer Res, 7(12), 2350-2394.

Malik, A., Ardalani, H., Anam, S., McNair, L. M., Kromphardt, K. J. K., Frandsen, R. J. N., Franzyk, H., Staerk, D., \& Kongstad, K. T. (2020). Antidiabetic Xanthones with $\alpha$-glucosidase Inhibitory Activities from An Endophytic Penicillium canescens. Fitoterapia, 142, 104522. doi:10.1016/j.fitote.2020.104522

Newman, D. J., \& Cragg, G. M. (2016). Natural Products as Sources of New Drugs from 1981 to 2014. J Nat Prod, 79(3), 629-661. doi:10.1021/acs.jnatprod.5b01055

Newman, D. J., \& Cragg, G. M. (2020). Natural Products as Sources of New Drugs over the Nearly Four Decades from 01/1981 to 09/2019. J Nat Prod, 83(3), 770-803. doi:10.1021/acs.jnatprod.9b01285

Puspitasari, E., Rozirwan, R., \& Hendri, M. (2018). Uji Toksisitas dengan menggunakan Metode Brine Shrimp Lethality Test (Bslt) Pada Ekstrak Mangrove (Avicennia Marina, Rhizophora Mucronata, Sonneratia Alba dan Xylocarpus Granatum) yang Berasal dari Banyuasin, Sumatera Selatan. Jurnal Biologi Tropis, 18, 91-103. doi:10.29303/jbt.v18i1.733

Ritna, A., Anam, S., \& Khumaidi, A. (2016). Identifikasi Senyawa Flavonoid Pada Fraksi Etil Asetat Benalu Batu (Begonia sp.) Asal Kabupaten Morowali Utara. Jurnal Farmasi Galenika (Galenika Journal of Pharmacy) (e-Journal), 2, 83-89. doi:10.22487/j24428744.2016.v2.i2.5957

Roopa, G., Madhusudhan, M. C., Sunil, K. C. R., Lisa, N., Calvin, R., Poornima, R., Zeinab, N., Kini, K. R., Prakash, H. S., \& Geetha, N. (2015). Identification of Taxol-producing endophytic fungi isolated from Salacia oblonga through genomic mining approach.J Genet Eng Biotechnol, 13(2), 119-127. doi:10.1016/j.jgeb.2015.09.002

Suhartina, S., Kandou, F. E. F., \& Singkoh, M. F. O. (2018). Isolasi dan Identifikasi Jamur Endofit pada Tumbuhan Paku Asplenium nidus. Jurnal MIPA, 7 (2), 24-28. doi:https://doi.org/10.35799/jm.7.2.2018.20640

Zubair, M. S., Alarif, W. M., Ghandourah, M. A., Anam, S., \& Jantan, I. (2020). Cytotoxic Activity of 2-O- $\beta$-glucopyranosil Cucurbitacin D from Benalu Batu ( Begonia sp.) Growing in Morowali, Central Sulawesi. 20(4), 7. doi:10.22146/ijc.43626

Zubair, M. S., Khairunisa, S. Q., Sulastri, E., Ihwan, Widodo, A., Nasronudin, \& Pitopang, R. (2021). Antioxidant and Antiviral Potency of Begonia medicinalis Fractions. Journal of basic and clinical physiology and pharmacology, 32(4), 845-851. doi:10.1515/jbcpp-2020-0476. (Accession No. 34214356) 